\title{
Effect of the Implementation of Occupational Health, Safety, and Regulation on Employee's Performance of Contractor Companies in Jakarta
}

\author{
Ricky Oktavianus ${ }^{1}$, Rosalendro Eddy Nugroho ${ }^{2}$ \\ ${ }^{1}$ Postgraduate Student of Civil Engineering, Mercu Buana University, Jakarta, Indonesia, \\ ${ }^{2}$ Lecturer of Civil Engineering, Mercu Buana University, Jakarta, Indonesia
}

Corresponding Author: Ricky Oktavianus

\begin{abstract}
Performance of employees is the key for the success of the company. This study makes the calculation about how the implementation of occupational health, safety, and the regulation of the company will affect the employee's performance. This research use 74 respondents from many contractor company in Jakarta, and the analysis of the data use SPSS (Statistical Product and Service Solutions) software. The result from this research found that the 3 variables independent can explain $63.2 \%$ from dependent variable (employee's performance), where variables occupational health and regulation have positive correlation with employee's performance with contribution of each variables $6.6 \%$ and $61.9 \%$ while variable safety has negative correlation with the dependent variable with contribution of $-5.3 \%$.
\end{abstract}

Keywords: employee's performance, SPSS, healthy, safety, regulation, contractor.

\section{INTRODUCTION}

The number of work accidents in Indonesia is still relatively high, the Ministry of Manpower said the problem of work accidents is still a challenge in the field of employment. The number of accidents and deaths in the last five years (2014-2018). It can be seen that in 2014 there were 105.383 accidents with 2.375 deaths. In 2015, there were 110.285 accidents with 2.308 deaths. In 2016, there were 101.367 accidents with 2.382 deaths. In 2017 , there were 123.000 accidents with
3.000 deaths (BPJS Ketenagakerjaan). Sector construction become one of the highest contributor of accident happened (about 31-35\% from total accident). To reduce the number of accidents, it is necessary to implement occupational health and safety, beside that is also important for company for making a strong regulation which requires the employees to comply with work safety (Priansa, 2014). Because the number of work accidents is reduced, it is believed to improve the performance of workers. Based on literature analysis, this study's objectives are:

- How much implementation of occupational health can affect the performance of the employee;

- How much implementation of safety can affect the performance of the employee;

- How much implementation of regulation can affect the performance of the employee.

\section{LITERATURE REVIEW}

Occupational safety and health are all activities to guarantee and protect the safety and health of workers through efforts to prevent accidents and occupational diseases (Government Regulatino no 50,2012). According to the behavioral approach to management, performance is a person's ability to achieve the goals that have been set and the level of success is high in carrying out a task. (Gibson et. al, 2012). Some researcher has made this kind 
of study, they analysis the implementation of occupational health and safety for employee's performance. Most of them got the positive result that show the implementation of occupational health and safety can increase the performance of the employee. But there is still some study that shows the implementation of those variables has negative correlation with performance. This study makes the analysis from implementation of occupational health, safety, and company regulation with employee's performance. With good regulation, the accident can be reduced (Prilia et al, 2012). However, variables occupational health, safety, regulation, and performance have some parameters which is described below:

- Occupational health parameters: (1) Clean work environment (2) Temperature at office (3) Exhaust system (4) Availability of clean water (5) Availability of health services (6) Availability of air vent (7) Availability of doctor at office (8) Medical check up

- Safety parameters: (1) Work tool placement (2) Personal protective equipment (3) Accident prevention tools (4) Outreach program (5) Control from leader (6) Punishment for violator (7) Reward for obedient

- Regulation parameters: (1) Clear level from a regulation (2) Justice of the regulation (3) Control from leader (4) Assertiveness from leader (5) Has a point about attendance (6)

- Performance parameters: (1)Quality (2) Quantity (3)Punctuality (4) Effectiveness from using materials (5) Attendance (6) Similarity between plan and reality (7) Knowledge about work (8) Attitude from employee Mentality from employee

\section{MATERIALS \& METHODS}

This study is a quantitative study, using questionnaires to 74 respondent whose working at contractor company in Jakarta. The questionnaires can be fulfil at Google form where the first 74 respondents will use their answer to analysis this study. This study basically finding the correlation between independent variables $(\mathrm{X})$ to dependent variable (Y). In this study, the first independent variable is occupational health (X1), the second independent variable is safety (X2) and the third independent variable is regulation of the company (X3). However, this study uses dependent variables employee's performance (Y). Some item of the questionnaire will represent each parameter of each variable $\mathrm{X}$ and $\mathrm{Y}$, as attached at literature review. Overall, variables $\mathrm{X} 1$ will has 18 questions, $\mathrm{X} 2$ will has 17 questions, $\mathrm{X} 3$ will has 14 questions, and $\mathrm{Y}$ will has 19 questions. Each question will represent about the parameter of each variables. The data analysis process with software SPSS (Statistical Product and Service Solutions) to produce the desires output. After all the respondents fulfill the questionnaires, data recap process is carried out. This study using Likert's scale where numbers 1-5 are used whose provisions are stated in the table 1 below.

Table 1 Measurement Scale

\begin{tabular}{|l|l|l|}
\multicolumn{3}{c}{ Table 1 Measurement Scale } \\
\hline Scale & Appraisal & Description \\
\hline 1 & $0 \%$ & Strongly disagree \\
\hline 2 & $25 \%$ & Disagree \\
\hline 3 & $50 \%$ & Neutral \\
\hline 4 & $75 \%$ & Agree \\
\hline 5 & $100 \%$ & Strongly agree \\
\hline
\end{tabular}

\section{Statistical Analysis}

First step before going to analysis the data is check for the validity and reliability. This study use Pearson's correlation for testing the validity of the data, and Cronbach's alpha for testing the reliability of the data. The statistical analysis about validity and reliability test is attached below.

Table 2 Validity test
\begin{tabular}{|l|l|}
\hline Variables & Pearson's correlation (sig) \\
\hline Occupational health (X1) & 0.00 \\
\hline Safety (X2) & 0.00 \\
\hline Regulation of company (X3) & 0.00 \\
\hline Employee's performance (Y) & 0.00 \\
\hline
\end{tabular}

From Table 2, the significant score of occupational health, safety, regulation, and employee's performance is 0.00 where 
Ricky Oktavianus et.al. Effect of the implementation of occupational health, safety, and regulation on employee's performance of contractor companies in Jakarta.

$0.00<0.05$. That's mean the questionnaire are valid.

Table 3 Reliability test

\begin{tabular}{|l|l|}
\hline Variables & Cronbrach's alpha \\
\hline Occupational health (X1) & 0.895 \\
\hline Safety (X2) & 0.940 \\
\hline Regulation of company (X3) & 0.936 \\
\hline Employee's performance (Y) & 0.912 \\
\hline
\end{tabular}

From Table 3, the Cronbach's alpha score is 0.895 for $\mathrm{X} 1,0.940$ for $\mathrm{X} 2,0.936$ for X3, and 0.912 for Y. That's means all the independent variables and dependent variable have score $>0.6$ which means all the questionnaire are reliable. Next analysis is normality test, multicollinearity test, heteroscedasticity test, and linearity test. The result of those tests attached below.

Table 4 Multicollinearity test

\begin{tabular}{|l|l|l|}
\hline Variables & Tolerance & VIF \\
\hline Occupational health (X1) & .235 & 4.260 \\
\hline Safety (X2) & .523 & 1.912 \\
\hline Regulation of company (X3) & .238 & 4.202 \\
\hline
\end{tabular}

From Table 4, the tolerance of $\mathrm{X} 1, \mathrm{X} 2$, and $\mathrm{X} 3$ are $>0.1$ and the $\mathrm{VIF}<10$ which means the data is not multicollinearity.

Table 5 heteroscedasticity test

\begin{tabular}{|l|l|}
\hline Variables & Sig \\
\hline Occupational health (X1) & 0.822 \\
\hline Safety (X2) & 0.456 \\
\hline Regulation of company (X3) & 0.261 \\
\hline
\end{tabular}

From Table 5, the sig of X1, X2, and $\mathrm{X} 3$ are $>0.05$ which means the data is not heteroscedasticity.

Table.6 Normality and linearity test

\begin{tabular}{|l|l|}
\hline Test & Sig \\
\hline Normality test & 0.08 \\
\hline Linearity test & 1.00 \\
\hline
\end{tabular}

From Table 6 the sig for normality test is 0.08 which is $0.08>0.05$ that's mean the data distribution is normal. And hence the sig for linearity test is 1.00 which is 1.00 $>0.05$ that's mean the model of this study is linear.

\section{RESULT}

From the result of data analysis obtained the value of $\mathrm{R}^{2}$ is 0.632 which means the independent variables (occupational health, safety, and regulation) can explain $63.2 \%$ from dependent variable (employee's performance). Where the $36.8 \%$ come from other variables that is not included in this study. The final result of this research is to make a formula about the relationship between independent variables and dependent variable so that the multiple linear regression analysis model is chosen.

Table 7 Multiple linear regression analysis

\begin{tabular}{|l|l|}
\hline Variables & Unstandarized Coefficient Beta \\
\hline Constant & 12.685 \\
\hline Occupational Health $(\mathrm{X} 1)$ & 0.142 \\
\hline Safety $(\mathrm{X} 2)$ & -0.085 \\
\hline Regulation $(\mathrm{X} 3)$ & 1.085 \\
\hline
\end{tabular}

From table 7, the formula for multiple linear regression analysis can be made, written below

$Y=12,685+0,142 X 1-0,085 X 2+1,085 X 3 . .(1)$

$\mathrm{Y}=$ employee's performance

$\mathrm{X} 1=$ occupational health

$\mathrm{X} 2$ = safety

$\mathrm{X} 3$ = regulation

Table 8 Proportion of each variables

Table 8 Proportion of each variables
\begin{tabular}{|l|l|l|}
\hline Variables & R Square & Proportion $(\%)$ \\
\hline Occupational Health $(\mathrm{X} 1)$ & 0.632 & 6.6 \\
\hline Safety & 0.632 & -5.3 \\
\hline Regulation & 0.632 & 61.9 \\
\hline
\end{tabular}

From Table 8 obtained the value of the proportion of the contribution of each variable to employee's performance where $\mathrm{X} 1$ has $6.6 \%$ contribution (positive correlation), $\mathrm{X} 2$ has $5.3 \%$ contribution (negative correlation) and X3 has $61.9 \%$ contribution (positive correlation).

\section{DISCUSSION}

From formula (1) it can be seen that variable occupational health (X1) has positive correlation with employee's performance (Y). Also regulation (X3) has positive correlation with employee's performance. The interesting thing is variable safety (X2) has negative correlation with employee's performance. That's mean, the implementation of safety will make the performance of the employee's decreased. The same thing was also found by Yankson Esi et al in their research entitled "The Effect Of Health And Safety Standart On Productivity In Ghana Rubber Estates Limited" and by Dr. Gabriel Dwomoh et al in their research entitled "Impact of 
occupational health and safety policies on employees' performance in the Ghana's timber industry". From those research, they concluded that the cause why variable safety has negative correlation with employee's performance caused by poor management of the company. The management doesn't do their work well with high discipline.

\section{CONCLUSION} below:

Conclusion of this research stated

- Variable occupational health has positive correlation to employee's performance

- Variable safety has negative correlation to employee's performance

- Variable regulation has positive correlation to employee's performance

- The independent variable can explain $63.2 \%$ of the dependent variable

- The linear regression model of this study is

$Y=12,685+0,142 X 1-0,085 X 2+1,085 X 3$

Acknowledgement: None

\section{Conflict of Interest: None}

\section{Source of Funding: None}

\section{REFERENCES}

1. Bavon, A., (2000), Occupational Health and Safety in Ghana. An Agenda for reform. African Social Science Review, $1(1), 37-46$.

2. O'Toole, M. (2002). The relationship between employees perceptions of safety and organizational culture. Journal of Safety Research 33: 231-243.

3. Pollitt, D. (2011). Corus forges new approach to safety and health. Human resource management international digest. Vol.19 No.1 pp.7-9.

4. Health and Safety Executive (2004). The development of case studies that demonstrate the business benefits of effective management of occupational health and safety. ISE Research Report. 249. Green Street Beman. HSE Books.
5. Daryanto, D. 2003. Keselamatan dan Kesehatan Kerja Bengkel. Jakarta: PT Bima Adiaksara dan PT Rineka Cipta.

6. Mangkunegara, Prabu, Anwar. 2013. Manajemen sumber daya manusia perusahaan. Bandung: PT Remaja Rosdakarya.

7. Undang-Undang Nomor 1 Tahun 1970. Tentang Keselamatan Kerja.

8. OHSAS 18001: 2007. Occupational Health and Safety Managemen System Requirements.

9. Schuler, Randall S. dan Jackson S.E. 1999. Manajemen Sumber Daya Manusia: Menghadapi abad ke-21. Erlangga. Jakarta.

10. Maryjoan, Iheanacho, Tom, Ebitu Ezekiel (2016). Effects Of Industrial Safety And Health On Employees' Job Performance In Selected Cement Companies In Cross River State, Nigeria. International Journal of Business and Management Review Vol.4, No.3

11. ILO. (2012). "Occupational injuries statistics from household and establishment surveys. Geneva

12. Gbadago, Patrick., Amedome, Sedem. N., Honyenuga Ben Q. (2017). “ The Impact of Occupational Health and Safety Measures on Employee Performance at the South Tongu District Hospital ".Global Journal of Medical Research: K Interdisciplinary

13. Esi, Yankson (2015). " The Effect Of Health And Safety Standards On Productivity In Ghana Rubber Estates Limited ".Institute of Distance Learning, Kwame Nkrumah University of Science and Technology

14. Dwomoh, G., Owusu, E.E., \& Addo, M. (2013). Impact of Occupational helath and Safety Policies on Employees Performance the Ghana's Timber Industry: Evidence from Lumber and Logs Limited. International Journal of Education and Research, 1 (12)

15. Olouch, Eric Omondi (2015). "Effect of Occupational Safety and Health Programmes On Employee Performance at Kenya Power Company Limited". University Nairobi 
Ricky Oktavianus et.al. Effect of the implementation of occupational health, safety, and regulation on employee's performance of contractor companies in Jakarta.

16. Widarjono, A. (2015). Analisis Multivariat Terapan dengan Program SPSS, AMOS, dan SmartPLS. Edisi Kedua. Yogyakarta: UPP STIM YKPN

17. Firmansyah, Afrizal. Hamid, Djamhur.Djudi, Mochamad (2017). Pengaruh Keselamatan dan Kesehatan Kerja Terhadap Kinerja Karyawan (studi pada Karyawan PT. PLN (persero) area
Kediri Distribusi Jawa Timur). Jurnal Administrasi Bisnis vol 42. No.2

How to cite this article: Oktavianus R, Nugroho RE. Effect of the implementation of occupational health, safety, and regulation on employee's performance of contractor companies in Jakarta. International Journal of Research and Review. 2021; 8(8): 528-532. DOI: https://doi.org/10.52403/ijrr.20210872 